\title{
EFFECT OF INHALATIONAL ANESTHETICS ON ACUTE KIDNEY INJURY
}

\author{
Martina Miklić Bublić ${ }^{1}$, Dinko Tonković ${ }^{1,2}$, Sanja Sakan ${ }^{3}$, Anita Misir ${ }^{1}$ and Daniela Bandić Pavlović ${ }^{1,2}$ \\ ${ }^{1}$ University Department of Anesthesiology, Resuscitation and Intensive Care, Zagreb University Hospital Center; \\ ${ }^{2}$ University of Zagreb, School of Medicine, Zagreb; ${ }^{3}$ Magdalena Special Hospital, Krapinske Toplice, Croatia
}

\begin{abstract}
SUMMARY - Acute kidney injury (AKI) is a serious complication associated with increased morbidity and mortality. Total incidence of AKI in hospitalized patients is 1\%-5\%. As many as 30\% of these patients develop AKI in the perioperative period, which is associated with anesthesia and surgery. Despite scientific advances and improved surgery techniques, as well as treatment in intensive care units, no significant decrease in AKI incidence has been achieved. To change this outcome, it is important to identify patients at risk of AKI and prevent its occurrence. Correct selection of anesthetic drugs during general anesthesia, adjusted to the individual needs of patients, also influences the overall outcome of treatment. Nowadays, inhalational anesthetics are not considered nephrotoxic. The more so, inhalational anesthetics have a strong and direct protective effect on many organs through preconditioning and postconditioning. New studies have shown that sevoflurane diminishes ischemia/ reperfusion kidney injury and has an anti-inflammatory effect, thus having the potential to reduce the occurrence of AKI. Given the incidence of AKI in the perioperative period, as well as new findings about anesthetics, the issue of anesthetic selection during general anesthesia might be of crucial importance for the final outcome of treatment.
\end{abstract}

Key words: Acute kidney injury; Anesthesia, general; Anesthetics, inhalation; Sevoflurane; Ischemia; Reperfusion injury

\section{Introduction}

The choice of general anesthesia best suited to the individual patient needs is of great importance, as the correct selection of anesthesia-inducing drugs can prevent unwanted effects on risk-group patients. In addition, it increases the effectiveness of the protective effects of individual anesthetics that have been proven in clinical practice, thus improving the outcome of treatment.

Acute kidney injury (AKI) in the perioperative period is characterized by acute kidney function reduction within 48 hours of surgery. In most cases, the

Correspondence to: Martina Miklic Bublic, MD, University Department of Anesthesiology, Resuscitation and Intensive Care, Zagreb University Hospital Center, Kišpatićeva 12, HR-10000 Zagreb, Croatia

E-mail:mmbublic@gmail.com

Received April 8, 2016, accepted June 27, 2016 damage is partially reversible, and recovery is expected within several weeks. Unfortunately, function recovery is complete only in $15 \%$ of patients. AKI is a serious perioperative period complication accompanied by increased mortality, morbidity and treatment costs. It is accompanied by the development and progression of chronic kidney disease, as well as an increased need for future dialysis, particularly in patients already suffering from disturbances in kidney function.

There are several classifications of AKI, previously known as acute renal failure, of which the most widely used are the Kidney Disease Improving Global Outcomes (KDIGO) and Risk, Injury, Failure and Endstage renal disease (RIFLE) classifications. The main characteristic of AKI is lost kidney function, which can be assessed by measuring serum creatinine levels as a measure of glomerular filtration rates, and by measuring urine output volume ${ }^{1}$. 
An increase in creatinine occurs only after a decrease in the glomerular filtration rate by more than $50 \%$. Therefore, it is not surprising that even a small serum creatinine increase is associated with increased short-term and long-term mortality, regardless of whether at the time of discharge from the hospital kidney function has partially or fully recovered. Consequently, even a minor creatinine increase needs to be considered seriously, as it represents significant kidney function damage ${ }^{2-7}$.

The incidence of AKI in surgery patients depends on the type of surgery. Some types of surgery associated with a high incidence of AKI development are cardiac surgery, abdominal and thoracoabdominal aneurysm surgery, and liver transplantation, while the incidence is significantly lower in general surgery. Despite new findings on AKI and improvements in surgery techniques and treatment in intensive care units, there has been no significant impact on this outcome. Therefore, identifying the risk groups and prevention of AKI occurrence are of extraordinary importance ${ }^{8,9}$. The results of risk factor studies are often analyzed according to the type of surgery. In a prospective study of patients undergoing major non-cardiac surgery, Kheterpal et al. found an increased risk of developing AKI in seven risk groups: patients older than 59 years, those with a body mass index greater than $32 \mathrm{~kg} / \mathrm{m}^{2}$, those with chronic obstructive pulmonary disease, liver disease or peripheral vascular occlusive disease, and urgent surgery and high-risk surgery patients ${ }^{10}$.

Knowing the preoperative, intraoperative and postoperative risk factors enables the introduction of precautionary measures in each particular perioperative period. Measures are aimed at the prevention of hemodynamic disorders and inflammatory changes, avoiding nephrotoxic drugs, and the prevention of metabolic disorders. In the preoperative period, optimization of the patient's condition is important. During anesthesia, emphasis is on the choice of anesthetics and on hemodynamic optimization, maintaining medium artery pressure (MAP $>65 \mathrm{~mm} \mathrm{Hg}$ ), adequate volume compensation and vasoactive drug administration. In the postoperative period, particularly in intensive care units, where patients are administered a large number of drugs, administration of nephrotoxic drugs should be avoided and drug dosage adapted to kidney function.

This review discusses the results of research investigating the use of inhalational anesthetics and their effect on kidney function.
For the time being, modern inhalational anesthetics are basic anesthetic agents, equally used for anesthesia maintenance and for anesthesia induction. Sevoflurane, isoflurane and desflurane are the most frequently administered inhalational anesthetics. The major anesthesiological effect of these gases is unconsciousness as a result of the central nervous system depression. In recent years, their non-anesthesiological characteristics, such as their direct effect on AKI, have been investigated.

\section{Preconditioning and Postconditioning of Inhalational Anesthetics}

It is known that the use of inhalational anesthetics ahead of an expected organ ischemia has a protective effect. This phenomenon is called anesthetic preconditioning ${ }^{11,12}$. Inhalational anesthetic agents have a neuroprotective effect owing to the activation of adenosine triphosphate (ATP)-dependent potassium channels. Sevoflurane preconditioning for 10 minutes significantly decreases the postoperative release of brain natriuretic peptide, a biochemical marker of myocardial contractile dysfunction. In addition, translocation of protein kinase $\mathrm{C}$ isoforms $\delta$ and $\varepsilon$ in human myocardium in response to sevoflurane preconditioning has been observed, as well as lower postoperative plasma cystatin $\mathrm{C}$ concentrations. This indicates better cardiac and renal function in patients.

The updated American Heart Association Guidelines recommend administering inhalational anesthetics during general anesthesia in non-cardiac surgery in hemodynamically stable patients at high risk of perioperative myocardial ischemia ${ }^{13}$.

Administering inhalational anesthetics after completion of ischemic injury protects several organs, including liver, heart and kidney, which is called anesthetic postconditioning ${ }^{14,15}$.

These facts open up new possibilities for AKI prevention and treatment.

In the past, administering inhalational anesthetics, particularly sevoflurane, was associated with nephrotoxicity as a result of the production of vinyl halide (compound A) during dehydrofluorination by carbon dioxide absorbers. Compound $\mathrm{A}$ has been shown to be nephrotoxic in rats ${ }^{16}$. Contrary to this are the results of the research conducted by Bito et al., who measured the impact of sevoflurane and isoflurane on blood urea 
nitrogen and serum creatinine concentration values, and on urinary excretion of the kidney-specific enzymes. The results of the study did not show any significant effects of compound A production during sevoflurane anesthesia on kidney function ${ }^{17}$.

\section{Modulation of Ischemia/Reperfusion Injury and Anti-Inflammatory Effects}

The major cause of AKI incidence is inflammatory reaction as a consequence of ischemic/reperfusion injury. Inflammatory response in tubules and endothelium causes breakdown of the endothelial basement membrane and inflammatory migration into the interstitial space. The inflammatory response can be reduced by activation of regulatory $\mathrm{T}$ lymphocytes further facilitating the production of anti-inflammatory mediators.

Inhalational anesthetics exert powerful multi-organ protective effects during the perioperative period and powerfully modulate ischemia/reperfusion injury. It has been proven that they activate multiple pathways to synthesize key cytoprotective and anti-inflammatory signaling molecules to attenuate ischemic AKI, as has been detailed by Fukazawa and Lee ${ }^{18}$. In ischemia/reperfusion kidney injury, proinflammatory cytokines are produced in dying or injured cells of proximal tubules, while the increasing number of chemokines attracting cytotoxic neutrophils and cytotoxic $\mathrm{T}$ lymphocytes additionally contributes to the local inflammatory response.

On the other hand, regulatory $\mathrm{T}$ cells produce antiinflammatory mediators, including transforming growth factor (TGF)-ß31 and interleukin (IL)-10, and express ectonucleoside triphosphate diphosphohydrolase (CD39) and ecto-5'-nucleotidase (CD73), which convert proinflammatory ATP into cytoprotective adenosine, which produces effects via A2a receptors. Thus, regulatory $\mathrm{T}$ cells protect the kidney from ischemic/reperfusion injury.

Inhalational anesthetics decrease nuclear translocation of $\mathrm{NF}-\kappa \mathrm{B}$, a key proinflammatory transcription factor ${ }^{19}$. Furthermore, inhalational anesthetics produce and promote anti-inflammatory mediators important for renal protection, including TGF- $\beta 1$ release, CD73 activation, and adenosine generation ${ }^{20-22}$.

Serum creatinine and estimated glomerular filtration rate as kidney function markers are insensitive to truly test the efficacy of the protective role of inhalational anesthetics. Recent research has been aimed at an early predictive marker of AKI, i.e. neutrophil gelatinase associated lipocalin (NGAL). A study of sevoflurane effects on renal function in rats after liver transplantation demonstrated significantly reduced NGAL concentrations in the sevoflurane group, as well as smaller epithelial necrosis. In the group anesthetized with sevoflurane, significantly lower serum concentrations of TNF- $\alpha$, IL- 6 , and myeloperoxidase were found 2 hours after reperfusion ${ }^{23}$.

In parallel with the increase in the number of studies demonstrating the protective role of sevoflurane against the occurrence of AKI, there is also a large number of studies on the protective effects of other anesthetics, such as propofol, with regard to AKI. While some studies point to a stronger protective effect of propofol as compared with sevoflurane relative to the occurrence of $\mathrm{AKI}^{24}$, others demonstrated that there were no statistically significant differences in the incidence of AKI between the two groups ${ }^{25,26}$.

\section{Conclusion}

Acute kidney injury in the perioperative period is a serious complication which often has an adverse effect on the course of treatment and outcome in surgical patients. This syndrome manifests with increased laboratory values of creatinine without clinical symptoms of anuria. The results of studies have shown higher mortality rates even in milder forms of AKI. The present-day approach aimed at reducing AKI incidence is based on applying precautionary measures in patients at risk during the perioperative period. AKI needs to be treated in a timely manner in order to ensure maximum kidney function recovery. It is also important to point out the multidisciplinary approach required for such patients, which includes an anesthesiologist, a surgeon, clinical pharmacologist and nephrologist.

The major cause of AKI incidence is inflammatory reaction as a consequence of ischemic/reperfusion injury. Modern inhalational anesthetics, such as sevoflurane and isoflurane, have immunomodulatory renoprotective effects based on the activation of regulatory $\mathrm{T}$ lymphocytes promoting the production of anti-inflammatory mediators. Study results confirm that administering inhalational anesthetics in patients at risk of developing AKI is justified. 
Given the above, it is concluded that the selection of the type of anesthetic during general anesthesia remains an important clinical issue, and that further research is needed to clarify the protective effect of inhalational anesthetics on the occurrence of AKI.

\section{References}

1. Thomas ME, Blaine C, Dawnay A, Devonald MAJ, Ftouh S, Laing $\mathrm{C}$, et al. The definition of acute kidney injury and its use in practice. Kidney Int. 2015;87:62-73. doi: 10.1038/ ki.2014.328

2. Lassnigg A, Schmidlin D, Mouhieddine M, Bachmann LM, Druml W, Bauer P, et al. Minimal changes of serum creatinine predict poor prognosis in patients after cardiothoracic surgery: a prospective cohort study. J Am Soc Nephrol. 2004;15:1597605. doi: 10.1097/01.ASN.0000130340.93930.DD

3. Ishani A, Nelson D, Clothier B, Schult T, Nugent S, Greer N, et al. The magnitude of acute serum creatinine increase after cardiac surgery and the risk of chronic kidney disease, progression of kidney disease, and death. Arch Intern Med. 2011; 171:226-33. doi: 10.1001/archinternmed.2010.514

4. Hobson CE, Yavas S, Segal MS, Schold JD, Tribble CG, Layon AJ, et al. Acute kidney injury is associated with increased longterm mortality after cardiothoracic surgery. Circulation. 2009;119:2444-53. doi: 10.1161/CIRCULATIONAHA.108. 800011

5. Bihorac A, Yavas S, Subbiah S, Hobson CE, Schold JD, Gabrielli A, et al. Long term risk of mortality and acute kidney injury during hospitalization after major surgery. Ann Surg. 2009; 249:851-8. doi: 10.1097/SLA.0b013e3181a40a0b

6. Lafrance JP, Miller DR. Acute kidney injury associates with increased long-term mortality.J Am Soc Nephrol. 2010;21:34552. doi: 10.1681/ASN.2009060636

7. Palevskky PM. Epidemiology of acute renal failure: the tip of the Iceberg. Clin J Am Soc Nephrol. 2006;2006:6-7. doi: 10.2215/CJN.01521005

8. Calvert S, Shaw A. Perioperative acute kidney injury. Periop Med. 2012;1:6. doi: 10.1186/2047-0525-1-6

9. Carmichael P, Carmichael AR. Acute renal failure in the surgical setting. ANZ J Surg. 2003;73(3):144-53. doi: 10.1046/ j.1445-2197.2003.02640

10. Kheterpal S, Tremper KK, Englesbe MJ, O'Reilly M, Shanks AM, Fetterman DM, et al. Predictors of postoperative acute renal failure after noncardiac surgery in patients with previously normal renal function. Anesthesiology. 2007;107:892902. doi: 10.1097/01.anes.0000290588.29668.38

11. Xiong L, Zheng Y, Wu M, Hou L, Zhu Z, Zhang X, et al. Preconditioning with isoflurane produces dose-dependent neuroprotection via activation of adenosine triphosphate-regulated potassium channels after focal cerebral ischemia in rats.
Anesth Analg. 2003;96:233-7. doi: 10.1213/00000539-20030 1000-00047

12. Julier K, da Silva R, Garcia C, Bestmann L, Frascarolo P, Zollinger A, et al. Preconditioning by sevoflurane decreases biochemical markers for myocardial and renal dysfunction in coronary artery bypass graft surgery: a double-blinded, placebo-controlled, multicenter study. Anesthesiology. 2003;98(6): 1315-27.

13. Fleisher LA, Beckman JA, Brown KA, Calkins H, Chaikof E, Fleischmann KE, et al. ACC/AHA 2007 Guidelines on Perioperative Cardiovascular Evaluation and Care for Noncardiac Surgery: Executive Summary: a report of the American College of Cardiology/American Heart Association Task Force on Practice Guidelines (Writing Committee to Revise the 2002 Guidelines on Perioperative Cardiovascular Evaluation for Noncardiac Surgery): developed in collaboration with the American Society of Echocardiography, American Society of Nuclear Cardiology, Heart Rhythm Society, Society of Cardiovascular Anesthesiologists, Society for Cardiovascular Angiography and Interventions, Society for Vascular Medicine and Biology, and Society for Vascular Surgery. Circulation. 2007;116:1971-96. doi: 10.1161/CIRCULATIONAHA.107. 185700

14. Beck-Schimmer B, Breitenstein S, Bonvini JM, Lesurtel M, Ganter M, Weber A, et al. Protection of pharmacological postconditioning in liver surgery: results of a prospective randomized controlled trial. Ann Surg. 2012;256:837-44. doi: 10.1097/ SLA.0b013e318272df7c

15. Pagel PS. Postconditioning by volatile anesthetics: salvaging ischemic myocardium at reperfusion by activation of prosurvival signaling. J Cardiothorac Vasc Anesth. 2008;22:753-65. doi: 10.1053/j.jvca.2008.03.005

16. Anders MW. Formation and toxicity of anesthetic degradation products. Annu Rev Pharmacol Toxicol. 2005;45:147-76. doi: 10.1146/annurev.pharmtox.45.120403.095847

17. Bito H, Ikeuchi Y, Ikeda K. Effects of low-flow sevoflurane anesthesia on renal function: comparison with high-flow sevoflurane anesthesia and low-flow isoflurane anesthesia. Anesthesiology. 1997;86:1231-7. doi: 10.1097/00000542-199706 000-00003

18. Fukazawa K, Lee HT. Volatile anesthetics and AKI: risks, mechanisms, and a potential therapeutic window. J Am Soc Nephrol. 2014;25(5):884-92. doi: 10.1681/ASN.2013111215

19. Lee HT, Ota-Setlik A, Fu Y, Nasr SH, Emala CW. Differential protective effects of volatile anesthetics against renal ischemiareperfusion injury in vivo. Anesthesiology. 2004;101:1313-24. doi: 10.1097/00000542-200412000-00011

20. Kim M, Ham A, Kim JY, Brown KM, D’Agati VD, Lee HT. The volatile anesthetic isoflurane induces ecto-59-nucleotidase (CD73) to protect against renal ischemia and reperfusion injury. Kidney Int. 2013;84:90-103. doi: 10.1038/ki.2013.43

21. Song JH, Kim M, Park SW, Chen SW, Pitson SM, Lee HT. Isoflurane via TGF-beta1 release increases caveolae formation and organizes sphingosine kinase signaling in renal proximal 
tubules. Am J Physiol Renal Physiol. 2010;298:F1041-F1050. doi: 10.1152/ajprenal.00115.2009

22. Lee HT, Chen SW, Doetschman TC, Deng C, D'Agati VD, Kim M. Sevoflurane protects against renal ischemia and reperfusion injury in mice via the transforming growth factor-beta1 pathway. Am J Physiol Renal Physiol. 2008;295:F128-F136. doi: 10.1152/ajprenal.00577.2007

23. Kong HY, Zhu SM, Wang LQ, He Y, Xie HY, Zheng SS. Sevoflurane protects against acute kidney injury in a small-size liver transplantation model. J Am Nephrol. 2010;32(4):347-55. doi:10.1159/000319623

24. Yoo YC, Shim JK, Song Y, Yang SY, Kwak YL. Anesthetics influence the incidence of acute kidney injury following valvu- lar heart surgery. Kidney Int. 2014;86(2):414-22. doi: 10.1038/ ki.2013.532

25. Story DA, Poustie S, Liu G, McNicol L. Changes in plasma creatinine concentration after cardiac anesthesia with isoflurane, propofol, or sevoflurane: a randomized clinical trial. Anesthesiology. 2001;95:842-8. doi: 10.1097/00000542-200110 000-00010

26. Menarguez AB, Martin GL, Suarez G, Martin MA, Ballesteros MR, Perez AP, et al. Retrospective comparative study between sevoflurane and propofol in maintaining anaesthesia during liver transplant: effects on kidney and liver function. Rev Esp Anestesiol Reanim. 2012;59(5):237-43. doi: 10.1016/j. redar.2012.03.021

Sažetak

\section{UČINAK INHALACIJSKIH ANESTETIKA NA AKUTNO OŠTEĆENJE BUBREGA}

\section{Miklić Bublić, D. Tonković, S. Sakan, A. Misir i D. Bandić Pavlović}

Akutno oštećenje bubrega (AOB) je ozbiljna komplikacija povezana s povišenim pobolom i smrtnošću. Ukupna incidencija AOB u bolničkih bolesnika iznosi 1\%-5\%. Čak 30\% tih bolesnika su razvili AOB u perioperacijskom razdoblju kao posljedicu anestezije i operacije. Unatoč novim znanstvenim spoznajama i unaprjeđenju kirurških tehnika te liječenja u jedinicama intenzivne njege, nije postignut značajniji pomak u smanjenju incidencije AOB. Za promjenu tog ishoda važno je prepoznavanje rizične skupine bolesnika te prevencija. Na ukupni ishod liječenja utječe i pravilan odabir anestetičkih sredstava tijekom opće anestezije, koji je najbolje prilagođen individualnim potrebama bolesnika. Danas se smatra da inhalacijski anestetici nisu nefrotoksični. Dapače, inhalacijski anestetici imaju snažan izravan zaštitni učinak na mnoge organe kroz predkondicioniranje i postkondicioniranje. Nova istraživanja pokazuju da sevofluran smanjuje ishemijsko-reperfuzijsku ozljedu bubrega i djeluje protuupalno, zbog čega ima potencijal smanjiti pojavu AOB. S obzirom na incidenciju AOB u perioperacijskom razdoblju i nove spoznaje o anesteticima, pitanje odabira anestetika tijekom opće anestezije moglo bi biti od ključnog značenja za sveukupni ishod liječenja.

Ključne riječi: Akutno oštećenje bubrega; Anestezija, opća; Anestetici, inhalacijski; Sevofluran; Ishemija; Reperfuzijska ozljeda 